\title{
US storage site delayed
}

\section{Washington}

THE United States' ability to produce nuclear weapons ran into new difficulties last week when Secretary of Energy James D. Watkins conceded that a new nuclearwaste storage site being dug underneath the New Mexico desert will not be ready on schedule. If the facility is not opened, the United States will have no place to store defence-related nuclear waste after the summer, forcing the Bush Administraion to find alternative storage sites or to suspend nuclear-weapons production.

Work on the $\$ 700$-million Waste Isolation Pilot Project (WIPP) - a 2,500-foot deep network of caves excavated in underground salt slabs near Carlsbad, New Mexico - has been put off many times since its inception in the early 1970 s. The series of caves was planned to hold transuranic wastes (intermediate-level radioactive wastes containing elements with atomic numbers higher than uranium) beginning in late 1988 or 1989 . But as construction progressed, the walls of the tunnels began to crack and seep brine, causing the project to be delayed until its long-term safety could be worked out.

In the meantime, the Department of

\section{ABORTION PILL}

\section{RU-486 still troubled Paris}

THE French abortifacient pill, RU-486, is at the centre of debate again, but this time for financial rather than moral reasons. Because the pill, which has been available for about a year, can be used only under strict government control (Nature 336, 4; 1988), patients should be able to claim reimbursement under the French social security system. The drug's maker, Roussel-Uclaf, saying that it needs to recoup the cost of twelve years of development, wants to charge FF517 (US\$78), but the Ministry of Health has fixed the value of the drug at FF93.5 (about US\$14).

The Health Ministry says that RousselUclaf has only to widen its market to reduce costs, but anti-abortion lobbies in other countries, notably the USA, have made its introduction outside France too sensitive for the manufacturers. Last year Roussel-Uclaf executives received death threats when the drug was first marketed in France. The product was withdrawn but was subsequently reintroduced after government intervention. Despite the new clash with the Health Ministry, the manufacturers have said they will not withdraw the drug. Meanwhile they are looking at less controversial applications for RU-486, especially its potential as a single-dose contraceptive taken at the end of the menstrual cycle. Peter Coles
Energy (DoE)'s Rocky Flats reactor outside Denver, Colorado has been producing 200 cubic yards of transuranic waste per month. Waste from Rocky Flats was supposed to go to WIPP as part of its five-year test period. Idaho has been accepting two boxcars of waste from Rocky Flats each month as an interim measure, because the Rocky Flats plant can store only 1,600 cubic yards.

The Rocky Flats waste has become a contentious issue in the states of Colorado, Idaho and New Mexico as the opening date of the WIPP storage pit has been repeatedly postponed. The governors of the three states accompanied Watkins on a site visit to WIPP last week, but made no concessions to ease DoE's waste-disposal problem. Idaho governor Cecil Andrus has said he will take only two more shipments of waste from Rocky Flats, and Colorado governor Roy Romer has pledged to close the Rocky Flats plant when waste levels reach 1,601 cubic yards.

Watkins, an admiral and former chief of naval operations, is now faced with scaling back production at Rocky Flats, negotiating with the Defense Department to place waste temporarily on a military installation or finding an alternative site. But other sites may be hard to come by: Nevada passed legislation last week banning nuclear waste to prevent DoE from shipping waste to Yucca Mountain, near the underground nuclear testing site. Forcing a state to accept nuclear waste would require a majority vote by both houses of Congress.

Watkins is also in a delicate position because the Federal Bureau of Investigations (FBI) has just begun an investigation of the Rocky Flats plant. The FBI alleges that DoE officials knowingly allowed the plant's managing contractor, Rockwell International, to release radioactivity into the environment and illegally store waste. FBI surveillance planes observed radioactive streams coming from an incinerator and a wastewater plant, and found unmarked barrels of waste. Watkins says that until the waste can be "validated" it will not be moved.

Prompted by the disarray in which he has found his department, Watkins also last week announced a plan to "create a new culture of accountability" within the DoE in environmental protection and waste management. The plan includes steps to bolster DoE's oversight of company contractors and facilitate the involvement of states, clean up current facilities and monitor more closely the effects of DoE activities on public health. Watkins also plans to set up an independent panel to review the WIPP storage site and to ask the US National Academy of Sciences to set up a similar panel.

Carol Ezzell

\section{US-Soviet monitoring}

Washington

THE US Natural Resources Defense Council (NRDC) and the Soviet Academy of Sciences are collaborating this week in experiments to assess the ability of passive radiation detectors to contribute to verification of limits on nuclear weapons at sea, the major stumbling block in the strategic arms reduction talks which resumed in Geneva two weeks ago.

The collaboration follows earlier joint projects in which NRDC sent monitoring teams to the Soviet Union to try to show that seismic monitoring could provide an accurate check on a test-ban treaty. NRDC is a private, non-profit environmentalprotection organization.

There will be a time limit on access to the warheads and limits on how closely the investigators may approach them. But by allowing US researchers access to nucleararmed warships, the Soviet Union seems to be making a greater show of commitment to solving problems of verification than is the United States. The experiments will be carried out in the Black Sea, where the teams have access to Slava-class cruisers armed with SS-N-22 SUNBURN cruise missiles. The US government is opposed to the experiment, and the US Navy refuses to confirm or deny that nuclear vessels are on board ships.

Both US and Soviet gamma-ray and neutron detectors will be used to detect the radiation from fissile material in the warheads. Similar experiments are thought to have been carried out by both the US and Soviet military on their own systems and on each others, but no data are available.

The detectors are of only limited use because of the difficulty of using them reliably to detect the radiation from fissile material in nuclear warheads at distances of more than a few feet, and because of the ease with which nuclear warheads can be sheltered from detection. But NRDC hopes to carry out similar experiments with 'active' detectors, which require a radioactive source or a pulsed neutron source. This equipment can detect forms of uranium that passive detection would miss.

Until verification measures are agreed, the United States is opposed to limits on deployment of sea-launched cruise missiles (SLCMs). The Soviet negotiators have proposed limitations of 400 nuclear SLCMs and 600 conventional SLCMs.

Christine McGourty

\section{GENOME SEQUENCING Flatworm's turn next?}

THE above would have been a more appropriate title for last week's item on the US National Institutes of Health programme to map and sequence the genome of the nematode roundworm (Nature 339, 648; 1989).

NATURE $\cdot$ VOL $340 \cdot 6$ JULY 1989 